\title{
Protective Mechanism of A20 Protein Over-expression in Rats with Acute Myocardial Infarction
}

\author{
$\mathrm{L} \mathrm{Li}^{1,2}, \mathrm{Z} \mathrm{Wu}{ }^{3}, \mathrm{E} \mathrm{Li}^{2}, \mathrm{~L}$ Zhang ${ }^{2}, \mathrm{~L} \mathrm{Li}^{1}$
}

\begin{abstract}
Objective: To investigate the protective mechanism of zinc finger protein A20 over-expression in acute myocardial infarction (AMI) rats.

Methods: Forty-five Sprague Dawley (SD) rats were randomly divided into sham group, model group and observation group. The model and observation groups were injected with normal saline and pcDNA3.1-A20 plasmid in the pre-operative 24 hour, respectively. The AMI model was established by ligating the left anterior descending coronary arteries of the model group and the observation group. The sham group were only treated with left anterior descending coronary artery threading but not ligation. The levels of A20 messenger ribonucleic acids $(m R N A)$ and protein were detected by, reverse transcription polymerase chain reaction (RT$P C R)$ and Western blot. The levels of tumour necrosis factor-alpha (TNF- $\alpha)$ and interleukin 6 (IL-6) proteins in the peripheral blood were detected by the enzyme-linked immunosorbent assay (ELISA). The myocardial infarct size was analysed by triphenyl tetrazolium (TTC) staining.

Results: Compared with the sham group, the levels of A20 $\mathrm{mRNA}$ and protein in the myocardium of the model and observation groups were significantly increased; the level in observation group was significantly higher than that of model group $(\mathrm{p}<0.05)$. Compared with sham group, the level of nuclear factor- $\kappa B(N F-\kappa B)$ p 65 protein in the myocardium of the model and observation groups was activated into the nucleus, and NF- $\kappa B$ p 65 protein in the nucleus in the observation group was significantly lower than that of the model group $(\mathrm{p}<0.05)$. Compared with the sham group, the levels of TNF- $\alpha$ and IL-6 proteins in the peripheral blood in the model and observation groups were significantly increased $(\mathrm{p}<0.05)$. The myocardial infarct size was significantly increased in the model and observation groups $(\mathrm{p}<0.05)$, while the myocardial infarct size in the observation group was significantly decreased compared with the model group $(\mathrm{p}<0.05)$.

Conclusion: Zinc finger protein A20 can significantly inhibit the inflammatory injury and cell apoptosis process in AMI rats, which may be related to its inhibition of the expression and activation of nuclear transcription factor $N F-\kappa B$.
\end{abstract}

Keywords: Acute myocardial infarction, NF- kB TNF- $\alpha$, Zinc finger protein A20

From: ${ }^{1}$ Department of Cardiovascular Internal Medicine, The First Affiliated Hospital of Zhengzhou University, Zhengzhou 450052, PR China, ${ }^{2}$ Department of Cardiovascular Internal Medicine and ${ }^{3}$ Department of Gerontology, The Second Affiliated Hospital of Zhengzhou University, Zhengzhou 450052, PR China.

West Indian Med J 2017; 66 (6): 690
Correspondence: Dr L Li, Department of Cardiovascular Internal Medicine, The First Affiliated Hospital of Zhengzhou University, No 1 Jianshedong Road, Zhengzhou 450052, Henan Province, PR China. Email: linglich

Email: linglichn@126.com 


\title{
EI Mecanismo Protector de la Sobreexpresión de la Proteína A20 en Ratas con Infarto Agudo de Miocardio
}

\author{
$\mathrm{L} \mathrm{Li}^{1,2}, \mathrm{Z} \mathrm{Wu}{ }^{3}, \mathrm{E} \mathrm{Li}^{2}, \mathrm{~L}$ Zhang ${ }^{2}, \mathrm{~L} \mathrm{Li}^{1}$
}

\begin{abstract}
RESUMEN
Objetivo: Investigar el mecanismo protector de la sobreexpresión de la proteína con dedos de zinc A20 en ratas con infarto agudo de miocardio (IAM).

Métodos: Cuarenta y cinco ratas Sprague Dawley (SD) fueron divididas aleatoriamente en un grupo simulado, un grupo modelo, y un grupo de observación. A los grupos modelo y de observación se les inyectó solución salina normal y el plásmido pcDNA3.1-A20 en las 24 horas preoperatorias, respectivamente. El modelo IAM se estableció ligando las arterias coronarias descendentes anteriores izquierdas del grupo modelo y el grupo de observación. El grupo simulado fue tratado enhebrando solamente la arteria coronaria descendente anterior izquierda, sin hacer la ligadura. Los niveles de proteína y ácidos ribonucleicos mensajero (ARNm) A20 fueron detectados mediante reacción en cadena de la polimerasa con transcripción inversa (RT-PCR, siglas en inglés) y electrotransferencia (Western blot). Los niveles de factor de necrosis tumoral alfa (FNT- $\alpha$ ) y las proteinas de interleucina 6 (IL-6) en la sangre periférica fueron detectados mediante ensayo por inmunoabsorción ligado a enzimas (ELISA). El tamaño del infarto del miocardio fue analizado mediante tinción con cloruro de trifenil tetrazolio (TTC).

Resultados: En comparación con el grupo simulado, los niveles de ARNm y proteína A20 en el miocardio de los grupos modelo y de observación se incrementaron significativamente; el nivel en el grupo de observación fue significativamente mayor que en el grupo modelo ( $<<0.05)$. En comparación con el grupo simulado, el nivel de proteína factor nuclear $\kappa B(N F-\kappa B)$ p65 en el miocardio de los grupos modelo y de observación fue activado en núcleo, y la proteína $N F-\kappa B$ p65 en el núcleo del grupo de observación fue significativamente menor que la del grupo modelo $(\mathrm{p}<0.05)$. En comparación con el grupo simulado, los niveles de las proteínas TNF- $\alpha$ e IL-6 en la sangre periférica en el grupo modelo y el grupo de observación, se incrementaron significativamente $(\mathrm{p}<0.05)$. El tamaño del infarto de miocardio aumentó significativamente en el grupo modelo y el grupo de observación ( $\mathrm{p}<0.05$ ), mientras que el tamaño del infarto del miocardio en el grupo de observación disminuyó significativamente en comparación con el grupo modelo $(\mathrm{p}<0.05)$.

Conclusión: La proteína con dedos de zinc A20 puede inhibir significativamente la lesión inflamatoria y el proceso de apoptosis celular en ratas con IAM, lo que puede estar relacionado con su inhibición de la expresión y activación del factor de transcripción nuclear NF- $\kappa B$.
\end{abstract}

Palabras clave: Infarto agudo de miocardio, NF-kB TNF- $\alpha$, proteína con dedos de zinc A20

West Indian Med J 2017; 66 (6): 691

\section{INTRODUCTION}

Acute myocardial infarction (AMI) refers to the sharp decrease or interruption of coronary artery blood supply, part of myocardium develops local acute necrosis due to severe and persistent ischaemia, thus, causing a series of symptoms and signs. Its main clinical manifestations include sudden chest pain, shortness of breath accompanied or not accompanied with haemodynamic disorder, arrhythmia, shock and heart failure $(1,2)$. Acute myocardial infarction is one of the most serious disease types in coronary heart disease and its early fatality rate is very high. The incidence of AMI in recent years has been gradually increasing and tends to a younger age group, which is one of the leading causes of human 
death. When the myocardial tissue develops more severe ischaemic injury, various inflammatory factors are activated accordingly and are continuously activated with a form of cascade amplification, which is involved in myocardial injury, repair and fibrosis $(3,4)$. Nuclear factor- $\kappa \mathrm{B}(\mathrm{NF}-\kappa \mathrm{B})$ is a transcription factor which has the effect of genetic transcription multidirectional regulation, and plays an important role in immune response, inflammatory response, cell proliferation, growth and apoptosis, cell adhesion, angiogenesis and tumour transformation (5). Recent studies showed that NF- $\kappa B$ also existed in vascular endothelial cells, vascular smooth muscle cells and myocardial cells, and was involved in the occurrence and development of many cardiovascular diseases. Therefore, as a key factor to mediate the inflammatory response, to inhibit the expression and activity of NF- $\kappa \mathrm{B}$ could effectively control the inflammatory injury (6). The zinc finger protein (A20) was also known as tumour necrosis factor alpha induced protein 3 (TNFAIP3), which is a ubiquitin modified enzyme, hardly expressed in normal myocardium tissues, but expressed in almost all organs and tissues during inflammatory reaction. Zinc finger protein A20 could inhibit the degradation of $I \kappa B \alpha$ for negative feedback regulation of NF- $\kappa \mathrm{B}$ induced inflammatory response $(7,8)$. In this study, the AMI model was established after injecting A20 plasmid into the rat, the protective effect of the myocardial cells was observed after myocardial injury and the mechanism of its action was investigated.

\section{SUBJECTS AND METHODS}

\section{Establishment of acute myocardial infarction rat model}

Healthy specific pathogen-free (SPF) grade male SD rats, with an average weight of $(192.8 \pm 10.65) \mathrm{g}$, were purchased from the Henan Experimental Animal Centre, Zhengzhou, China. Forty-five rats were randomly divided into the: sham, model and observation groups. The rats in the model and observation groups were injected with saline and plasmid pcDNA3.1-A20, respectively through the tail vein in pre-operative 24 hours. The rats in the model and observation groups were intraperitoneally injected with $50 \mathrm{mg} / \mathrm{kg}$ sodium pentobarbital for anaesthesia.

The rats were fixed on the test bench, a vertical incision was made in the middle of the neck. The subcutaneous tissues and glands were separated to expose the trachea and an oral trachea cannula was conducted. The skin was cut open along the left border of the sternum fourth intercostal space. The subcutaneous tissue and thoracic muscles were bluntly separated layer by layer. The intercostal space was cut open with small ophthalmic scissor so as to open the left cardiac chamber. The pericardium was cut open. The 5-0 double needle noninvasive suture was used to pass through the left anterior descending coronary artery.

The needle depth was about $1.0 \mathrm{~mm}$. The left anterior descending coronary artery was ligated (The myocardial colour in the distal ligation was observed before and after the anterior descending artery was ligated. If the local myocardial colour was darkened, the ligation was successful). The thoracic cavity was closed and sutured with No. 0 thread. Penicillin was locally used to prevent postoperative infection. After the rats recovered spontaneous breathing, the tracheal catheter was pulled out. The coronary artery was not ligated in the rats in the sham group.

The remaining operations were similar with that of the operation group. Blood was drawn from the inferior vena cava in postoperative 24 hours period. The rats were sacrificed. The heart was quickly removed, rinsed with saline to wipe-off adipose tissue and non-cardiac tissue and dried-up with filter paper. The myocardial segment with maximum ventricular circumference was taken out. This study was performed in strict accordance with the recom-mendations in the Guide for the Care and Use of Laboratory Animals of the National Institutes of Health (Bethesda, MD, United states of America (USA). Eighth Edition, 2010. The animal use protocol was reviewed and approved by the Institutional Animal Care and Use Committee (IACUC) of the First Affiliated Hospital of Zhengzhou University.

\section{Reverse transcription-polymerase chain reaction}

$0.1 \mathrm{~g}$ rat myocardial tissue was removed in each group and cut into small pieces and placed in a glass homogenizer, $1 \mathrm{~mL}$ Trizol (TaKaRa, Dalian, China) was added and homogenized into non-granular transparency. The homogenate was transferred to $1.5 \mathrm{~mL}$ Eppendorf (Ep) tube and centrifuged. The supernatant was transferred to a new Ep tube, $200 \mu 1$ chloroform was added, fully mixed then centrifuged by 12000 revolutions per minute (rpm) for 15 minutes. The supernatant was transferred to a new $1.5 \mathrm{~mL}$ Ep tube. Isopyknic isopropanol was added and mixed and allowed to stand for 20 minutes then centrifuged by $12000 \mathrm{rpm}$ for 10 minutes. The supernatant was discarded. The pre-cooling 75\% ethyl alcohol was added, centrifuged by $7500 \mathrm{rpm}$ for five minutes and repeated 
twice. RNase-free water was added for dissolution. The sample concentration was determined. Ribonucleic acids (RNA) was transcribed into cDNA by a reverse transcription kit (TaKaRa, Dalian, China), which was taken as the template for polymerase chain reaction (PCR). According to A20 mRNA sequences provided in Genebank, the primers were designed as follows: A20-F: 5'-TTTGAGCAATATGCGGAAAGC-3', A20-R: 5'-AGTTGTCCCATTCGTCATTCC-3'.

$\beta$-Actin was taken as the internal reference: $\beta$-Actin-F: 5'-AGGCTGTGTTGTCCCTGTA-3', $\quad \beta$-Actin-R: ATGTCACGCACGATTTCC-3'. The primer was diluted to $10 \mu \mathrm{mmol} \cdot \mathrm{L}-1$. Polymerase chain reaction system was prepared after the optimization of primer specificity and annealing temperature. The total reaction volume was $20 \mu \mathrm{l}$. The PCR was conducted according to the following reaction conditions: predenaturation at $94{ }^{\circ} \mathrm{C}$ for two minutes, denaturation at $94{ }^{\circ} \mathrm{C}$ for 30 seconds, annealing extension at $60{ }^{\circ} \mathrm{C}$ for 30 seconds and extension at $72{ }^{\circ} \mathrm{C}$ for 30 seconds, a total of 35 cycles. To determine the specificity of the product, the solubility curve was constructed. Finally, the data were read directly from the real-time fluorescence quantitative PCR instrument (Applied Biosystems, Foster City, CA, United States of America (USA).

\section{Western blot}

One hundred milligram myocardial tissues of rats in each group was removed and cut into pieces with the ophthalmic scissors. The total protein and nucleoprotein were extracted by the kit instructions. The cytoplasm protein and nucleoprotein were detected by the bicinchoninic acid assay (BCA) protein detection kit (Jingmei Inc, Nanjing, China). The $4 *$ loading buffer was added and boiled for 30 minutes. The protein was transferred on polyvinylidene difluoride (PVEF) membrane, after sodium dodecyl sulphate-polyacrylamide gel electrophoresis (SDS-PAGE) separation and closed with 5\% skim milk powder for 30 minutes.

The rabbit anti-rat A20 monoclonal antibody ([1:5000 dilution] (Santa-Cruz, CA, USA) and rabbit anti-rat NF- $\kappa$ B p65 monoclonal antibody [1:2000 dilution] (Santa-Cruz, CA, USA) were added respectively, incubated at $4{ }^{\circ} \mathrm{C}$ overnight. Washed three times with phosphate buffered saline solution with the detergent Tween ${ }^{\circledR} 20$ (PBST), five minutes/time. The rat anti-rabbit IG monoclonal antibody (Santa-Cruz, CA, USA) was added and incubated for one hour. Diaminobenzidine (DAB) developing, photographed.
The $\beta$-actin and Lamin B were taken as the internal references. The gray of the target protein band was analysed with the gray calculation software. The relative expression of target protein was calculated.

\section{ELISA analysis}

Five-millilitres of venous blood was extracted from the inferior vena cava of rats in each group, respectively. It was allowed to stand quietly at room temperature for 30 minutes, then centrifuged by $3000 \mathrm{rpm}$ for $10 \mathrm{~min}$ utes. The supernatant was packed in $1.5 \mathrm{~mL}$ Ep tube and stored at $-80{ }^{\circ} \mathrm{C}$ refrigerator. The procedure was in strict accordance with the instructions of the ELISA kit (Jingmei Inc, Nanjing, China). The concentrations of TNF- $\alpha$ and IL- 6 were detected. Three complex holes were set for each sample and standard. The optical density (OD) value was measured at $492 \mathrm{~nm}$ with the microplate reader (Thermo Scientific, Rockford, IL, USA). The average value was calculated.

\section{Triphenyl tetrazolium chloride staining}

The rats in each group were sacrificed. The heart was quickly taken out and washed with PBS. The atrium and right ventricle were cut off. The left ventricle was left in, quick-frozen at $-20{ }^{\circ} \mathrm{C}$ for 20 minutes, then cut into pieces with the freezing microtome. The thickness of each piece was $2 \mathrm{~mm}$. The sections were placed in preheated $37{ }^{\circ} \mathrm{C}$ triphenyl tetrazolium chloride (TTC) staining solution (Sigma, St Louis, MO, USA) and incubated at $37{ }^{\circ} \mathrm{C}$ for 15 minutes away from light. The myocardial tissue was turned over for homogeneous staining, then washed with PBS three times. At this time, the infarction area was white and noninfarct area was deep red. The different staining area was measured with the image processing software. Myocardial infarct size $=$ (infarct size/ myocardial area * myocardial weight of the section)/ left ventricular weight $* 100$.

\section{Statistical analysis}

All data were analysed by SPSS 17.0 statistical software (SPSS Inc, Chicago, IL, USA). The measurement data were expressed with $\mathrm{X} \pm \mathrm{S}$. The measurement data among multiple groups were compared with analysis of variance. Least significance difference method was used to compare the difference between two two groups, $p<0.05$ indicated the difference was statistically significant. 


\section{RESULTS}

\section{Comparisons of A20 mRNA and protein levels in myocardial tissues of rats in all groups}

As shown in Fig. 1, A20 was not expressed in the myocardial tissue of normal rats and was significantly increased in AMI rats, the levels of A20 mRNA and protein in myocardial tissue of rats in the observation group were significantly higher than those of the model group and the difference was statistically significant $(p<0.05)$.

\section{Comparisons of $\mathrm{NF}-\kappa \mathrm{B}$ protein in myocardial tissue of rats in all groups}

The analysis results of NF- $\mathrm{B}$ p 65 protein levels in myocardial tissue of rats in all groups were shown in Fig 2. Compared with the sham group, the levels of NF- $\mathrm{kB}$ protein in the myocardial cell nuclei in the model and observation groups were significantly increased $(p<$ $0.05)$, the level of NF- $\mathrm{B}$ p 65 protein in the model group was significantly higher than that of the observation group $(p<0.05)$.

\section{Comparison of TNF- $\alpha$ and IL-6 in peripheral blood of rats in all groups}

The ELISA detection result showed that compared with the sham group, the levels of TNF- $\alpha$ and IL-6 protein in the model and observation groups were significantly increased $(p<0.05)$. Of which, the levels of TNF- $\alpha$ and IL-6 proteins were significantly higher than that of the observation group and the difference was statistically significant $[p<0.05]$ (Fig. 3).

\section{Comparison of myocardial infarct size of rats in all groups}

Compared with the sham group, the myocardial infarct size was significantly increased in the model and observation groups $(p<0.05)$. The myocardial infarct size in the observation group was significantly lower than that of the model group and the difference was statistically significant $[p<0.05]$ (Fig. 4).

\section{DISCUSSION}

It is generally believed that the occurrence of acute myocardial infarction is closely related to blood vessel blockage due to coronary artery atherosclerosis plaque rupture, resulting in myocardial ischaemia and necrosis. The myocardial ischaemic and hypoxic damage caused by thrombogenesis, sharp decrease even interruption of coronary blood supply when AMI occurs, afterwards induces excessive inflammation of the injured part, leading to myocardial cell necrosis and apoptosis. The study showed that the inflammatory cytokine was the factor that increased the myocardial cell apoptosis. It can cause the structural and functional damage to the myocardial cells through activating cytotoxic $\mathrm{T}$ cells (9-11). Nuclear factor- $\mathrm{kB}$ is a transcription factor having genetic transcription multidirectional regulation. When the cells were in the resting state, NF- $\kappa \mathrm{B}$ combined with $\mathrm{I} \kappa \mathrm{B}$ into tripolymer in the form of dimer, existing in the cytoplasm in the form of non-activate state. When the cells were stimulated by some extracellular signals, NF- $\kappa \mathrm{B}$ could be activated, resulting in genetic transcription and increase of binding with nuclear DNA, which induced myocardial cell apoptosis, caused or aggravated heart-failure. The relationship between inflammatory reaction induced by NF- $\kappa \mathrm{B}$ and cell apoptosis played an important role in the occurrence and development of AMI $(12,13)$.

The AMI rat model was established. The NF- $\kappa \mathrm{B}$ in myocardial cell nuclei of rats was detected by Western blot method. The results showed that the level of NF- $\mathrm{BB}$
A

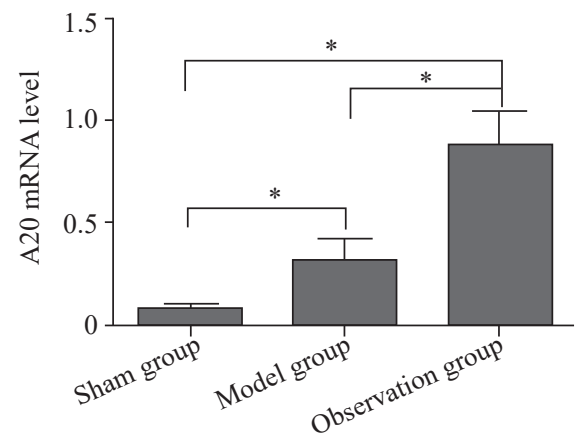

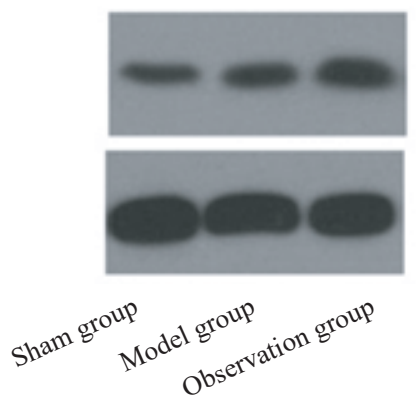

C

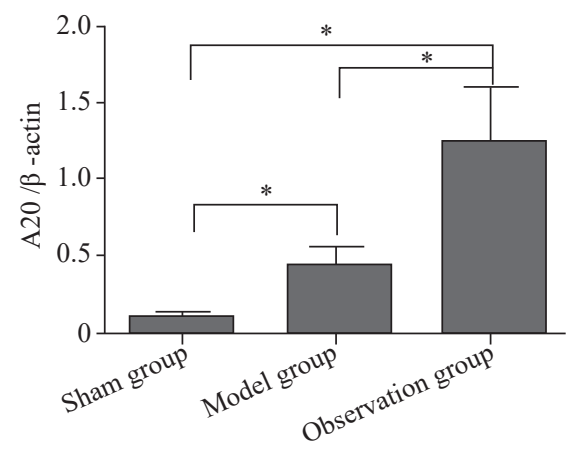

Fig. 1: Comparisons of A20 mRNA and protein levels in myocardial tissues of rats in all groups.

A. A20 mRNA expression. B. Western blot detection result. C. quantitative analysis of the A20 protein expression. 
protein in myocardial cell nuclei of AMI rats was significantly increased, indicating that AMI activated NF- $\mathrm{KB}$ and transferred into the nuclei, so as to be involved in the regulation and control of many inflammatory cytokines as well as the expressions of many genes. Among them, TNF- $\alpha$ and IL- 6 were the main inflammation promoting factors in the occurrence and development of AMI. They could cause the structural and functional disorder of myocardial cells by activating cytotoxic $\mathrm{T}$ cells, could cause inflammatory reaction syndrome and aggravate myocardial hypoxia. In this study, the levels of TNF- $\alpha$ and IL-6 in the peripheral blood of AMI rats were detected by ELISA method. The result showed that compared with the sham group, the levels of TNF- $\alpha$ and IL- 6 in the peripheral blood of AMI rats were significantly increased.

The levels of TNF- $\alpha$ and IL- 6 were positively correlated with the levels of nuclear NF- $\mathrm{KB}$, indicating that

A

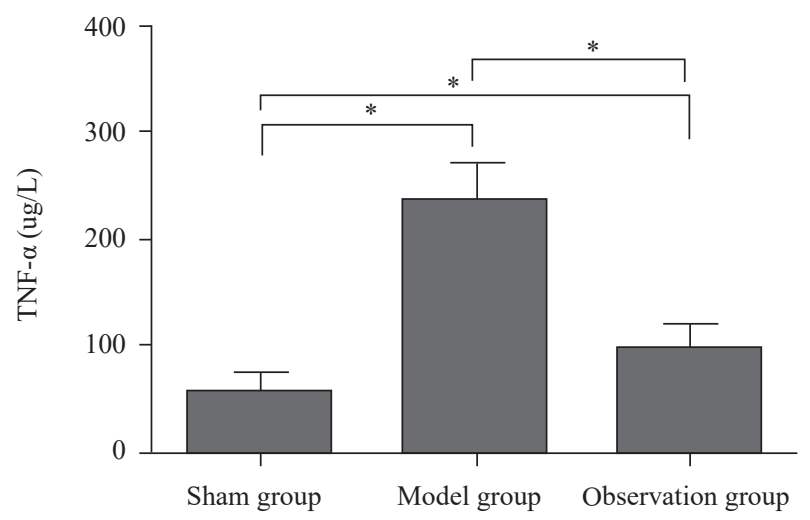

the activated NF- $\mathrm{\kappa B}$ could induce the upregulation of inflammatory cytokines, the upregulated inflammatory cytokines could activate NF- $\kappa \mathrm{B}$, so as to form the complex inflammation activating network.

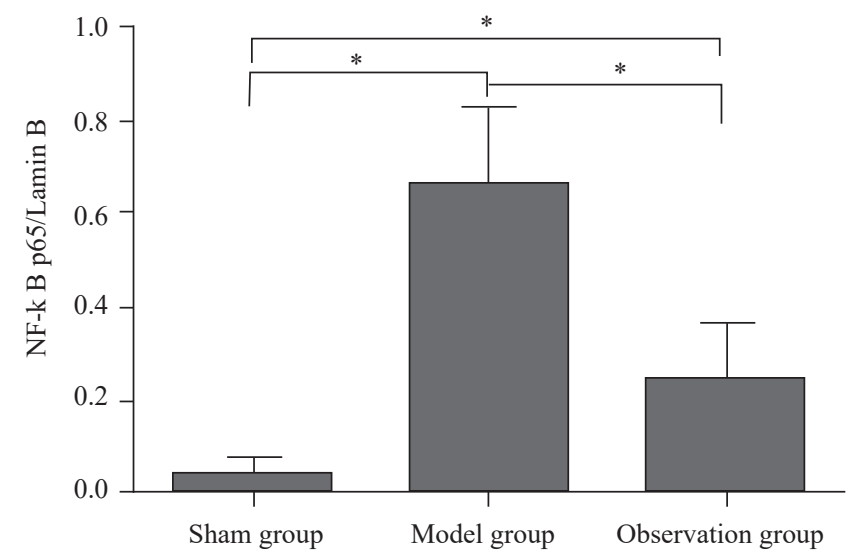

Fig. 2: Comparisons of NF- $\mathrm{kB}$ protein in myocardial tissue of rats in all groups.

B

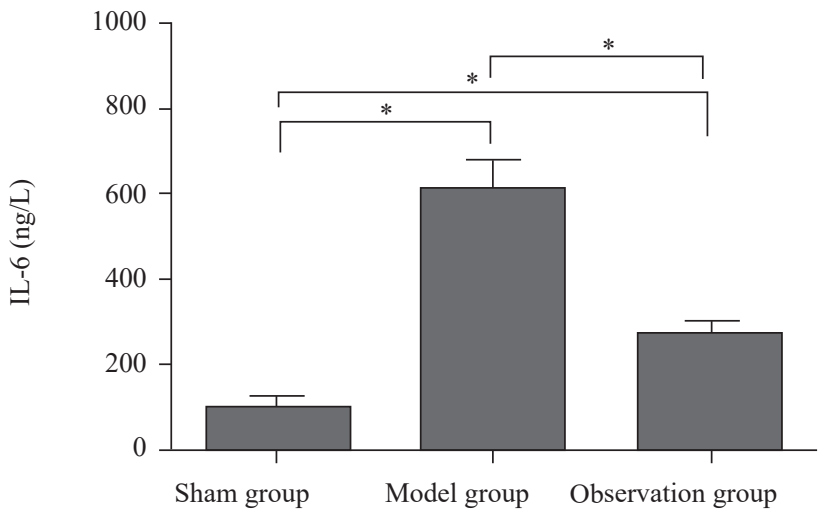

Fig. 3: Comparison of TNF- $\alpha$ and IL-6 in peripheral blood of rats in all groups.

A

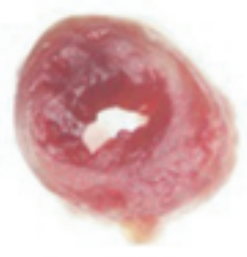

Sham group

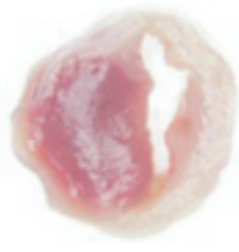

Model group

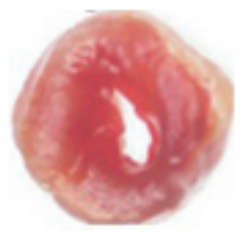

Observation group
A. TNF- $\alpha$ protein levels in peripheral blood.

A. TTC staining analysis result.
B

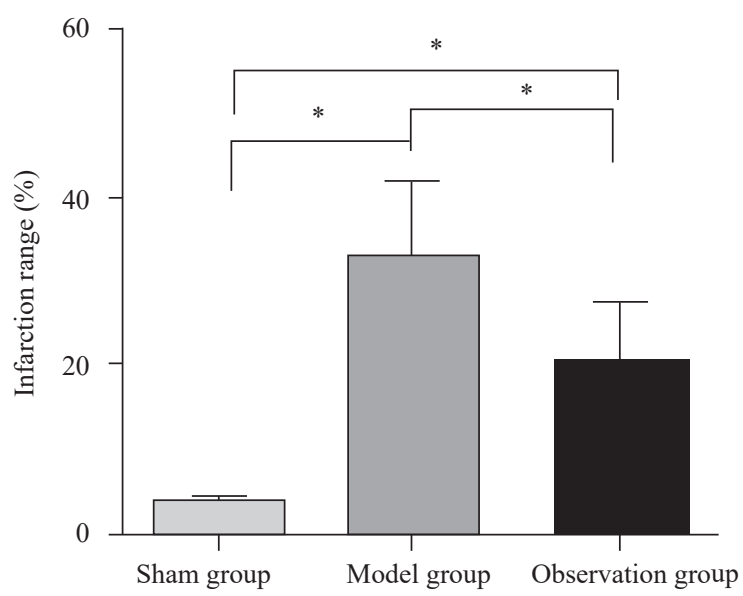

B. IL-6 protein levels in peripheral blood.

B. quantitative analysis showed the myocardial infarct size in all groups.

Fig. 4: Comparison of myocardial infarct size of rats in all groups. 
A20 is a kind of cytoplasm inflammation regulatory protein that belongs to the protein in inflammation negative regulatory system, which is also known as antiapoptotic protein. It plays an important protective role in the inflammatory reaction. It is an essential functional protein which can prevent the uncontrolled inflammatory reaction. Under normal physiological conditions, A20 existed in the cytoplasm in the non-active state (14). studies at home and abroad showed that the activation of $\mathrm{NF}-\kappa \mathrm{B}$ stimulated the high expression of A20. The A20 inhibited the activation of NF- $\kappa \mathrm{B}$ and the expression of the main membrane receptor TLR4 mediating cell inflammatory response, so as to intervene in the expressions of TNF-a and IL-6 etc, which played an important protective role for tissue inflammatory injury $(15,16)$.

In this study, the levels of A20mRNA and protein in the myocardial tissue of AMI model rats were detected by RT-PCR and Western blot methods. The results showed that the occurrence of AMI could activate the stress expression of endogenous A20 in vivo, which played a protective role in myocardial tissue. However, the deficient expression of endogenous A20 was not enough to fully protect the myocardial injury induced by AMI. In this study, the myocardial infarct size of AMI rats was significantly higher than that of the sham group, which proved the viewpoint. Therefore, in order to further explore the protective mechanism of A20 on myocardial injury, before we established AMI model 24 hours, the plasmid carrying A20 gene was injected into rats via the tail vein. The detection results showed that the expression of A20 in AMI rats injected with A20 plasmid was significantly higher than that of the model and sham groups. The expressions of NF- $\kappa \mathrm{B}$ p 65 , TNF-a and IL-6 were significantly lower than those of the model and sham groups and the myocardial infarct size was significantly lower than that of the model group. This result proved the inhibiting effect of A20 on $\mathrm{NF}-\mathrm{kB}$ signal pathway and protective effect on inflammatory injury.

In conclusion, the expression of A20 in AMI rats can significantly reduce inflammation, reduce the pathological damage of myocardial tissue and, thus, achieve the protective effect of myocardial tissue. Its mechanism is closely related to the negative feedback regulation of $\mathrm{NF}-\kappa \mathrm{B}$ signal transduction pathway.

\section{ACKNOWLEDGEMENTS}

This work was supported by grants from the key scientific research projects of Colleges and uni $\neg$ versities in Henan Province (No. 15A320019) and the science and technology projects in Henan province (No. 142102310109).

\section{REFERENCES}

1. Bashar T, Akhter N. Study on oxidative stress and antioxidant level in patients of acute myocardial infarction before and after regular treatment. Bangladesh Med Res Counc Bull 2014; 40: 79-84.

2. Yoon HJ, Kim KH, Kim JY, Cho JY, Yoon NS, Park HW et al. Impaired diastolic recovery after acute myocardial infarction as a predictor of adverse events. J Cardiovasc Ultrasound 2015; 23: 150-7.

3. Zhang XF, Hu DY, Ding RJ, Wang HC, Yan LX. Status and trend of cardio-cerebral-vascular diseases mortalityin China: data from national disease surveillance system between 2004 and 2008. Chin J Cardiol 2012; 40: 179-87.

4. Freeman PM, Moschonas KE, Hinz C, O'Donnell VB, Kinnaird TD, James PE, Anderson RA. Changes in platelet function independent of pharmacotherapy following coronary intervention in non-ST-elevation myocardial infarction patients. Atherosclerosis 2015; 243: 320-7.

5. Wang Y, Park NY, Jang Y, Ma A, Jiang Q. Vitamin E $\gamma$-Tocotrienol inhibits cytokine-stimulated NF- $\mathrm{NB}$ activation by induction of antiinflammatory A20 via stress adaptive response due to modulation of sphingolipids. J Immunol 2015; 195: 126-33.

6. Sun B, Che XM, Gu SX. Effects of A20 suppressing NF - $\kappa$ B expression on neural apotosis and functional recovery in a mouse spinal cord injury model. Chin J Neurosurg 2012; 28: 615-8.

7. Bannon A, Zhang SD, Schock BC, Ennis M. Cystic fibrosis from laboratory to bedside: the Role of A20 in NF- $\kappa \mathrm{B}-$ mediated inflammation. Med Princ Pract 2015; 24: 301-10.

8. Liu YG, Wu LJ. Research progress of the effect and mechanism of zinc finger protein A20 in regulating inflammatory signal. Int J Lab Med 2013; 34: 448-50.

9. Park JS, Min JH, Kang JH, In YN. Acute myocardial infarction due to stent thrombosis after administration of intravenous epinephrine for anaphylaxis. Chin Med J (Engl) 2015; 128: 2692-3.

10. Su Y, Wang L, Zhang MZ. Advances in the epidemiology of acute myocardial infarction. J Integ Trad Chin and West Med 2012; 10: 467-8.

11. Devaux Y, Vausort M, Azuaje F, Vaillant M, Lair ML, Gayat E et al. Low levels of vascular endothelial growth factor B predict left ventricular remodeling after acute myocardial infarction. J Card Fail 2012; 18: 330-7.

12. Gui J, Yue Y, Chen R, Xu W, Xiong S. A20 (TNFAIP3) alleviates CVB3induced myocarditis via inhibiting NF-kappaB signaling. PLoS One 2012; 7: e46515.

13. Shi X, Qian T, Li M, Chen F, Chen Y, Hao F. Aberrant Low Expression of A20 in tumor necrosis factor- $\alpha$-stimulated SLE monocytes mediates sustained NF- $\kappa$ B inflammatory response. Immunol Invest 2015; 44: 497-508.

14. Gurung P, Man SM, Kanneganti TD. A20 is a regulator of necroptosis. Nat Immunol 2015; 16: 596-7.

15. Yao D, Gong KZ, Zhang ZG. Progress in zinc finger protein A20 and cardiovascular disease. Chin J Clins (Electronic Edition) 2014; 8: 2494-8.

16. Siracuse JJ, Fisher MD, da Silva CG, Peterson CR, Csizmadia E, Moll $\mathrm{HP}$ et al. A20-mediated modulation of inflammatory and immune responses in aortic allografts and development of transplant arteriosclerosis. Transplantation 2012; 93: 373-82. 